\title{
KAJIAN TENTANG RELEVANSI PERADILAN ADAT TERHADAP SISTEM PERADILAN PERDATA INDONESIA*
}

\author{
Tody Sasmitha Jiwa Utama** dan Sandra Dini Febri Aristya ${ }^{* * *}$ \\ Bagian Hukum Adat dan Bagian Hukum Acara \\ Fakultas Hukum Universitas Gadjah Mada, Yogyakarta \\ Jalan Sosio Yustisia Nomor 1, Bulaksumur, Sleman, D.I. Yogyakarta 55281
}

\begin{abstract}
The position of adat court in Indonesia civil legal system has a long history. Distinction of public or private sphere would appear when adat court decisions in contact with national judicial system. Interaction between both systems isn't ideal, either at the level of norms and practices. Unification policy of judiciary institution is one cause which make adat court was forgotten. Although the Judicial Authority Law opens possibility of resolving civil cases by agreement based mechanism, it requires the various perspectives both of legal-normative regarding the existence of adat court and the law implementation prespective regarding Indonesian civil justice system.
\end{abstract}

Keywords: adat justice, civil judiciary system.

\section{Intisari}

Kedudukan peradilan adat dalam sistem peradilan perdata nasional memiliki sejarah panjang. Pembedaan ranah publik or privat muncul ketika putusan pengadilan adat bersentuhan dengan ranah sistem peradilan nasional. Hingga saat ini, interaksi antara keduanya belum ideal, baik pada tataran norma maupun praktek. Kebijakan unifikasi badan peradilan menjadi salah satu penyebab peradilan adat lambat laun mulai ditinggalkan. Undang-Undang Kekuasaan Kehakiman membuka kemungkinan upaya penyelesaian perkara perdata secara perdamaian sebagai semangat yang termanifestasi dalam sistem peradilan perdata. Oleh sebab itu, perlu dikaji dari sisi legal-normatif mengenai keberadaan pengadilan adat dan secara empiris melalui implementasi aturan tersebut dalam sistem peradilan perdata Indonesia.

Kata Kunci: pengadilan adat, peradilan perdata.

\section{Pokok Muatan}

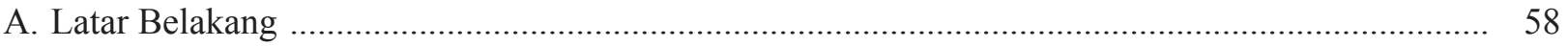

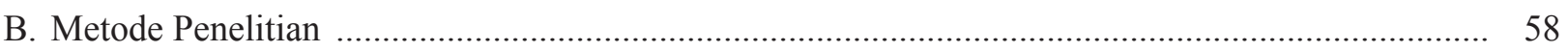

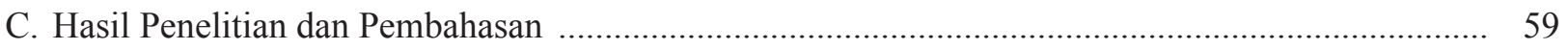

1. Pengakuan dan Kedudukan Peradilan Adat dalam Sistem Peradilan Perdata Nasional ............. 59

2. Interkoneksi antara Sistem Peradilan Perdata Nasional dengan Peradilan Adat ........................ 62

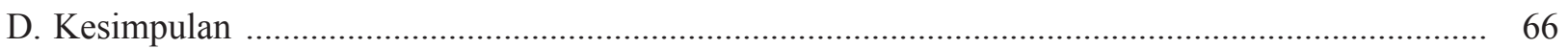

\footnotetext{
Hibah Penelitian Fakultas Hukum Universitas Gadjah Mada Tahun 2014.

** Alamat korespondensi: todysasmitha@gmail.com

*** Alamat korespondensi: sandra_aristya@yahoo.fr
} 


\section{A. Latar Belakang}

Penyelesaian sengketa berbasis komunitas, yang kerap disebut juga sebagai pengadilan adat ini mulai mendapat perhatian kembali setidaknya dalam berbagai forum ilmiah dan organisasi masyarakat sipil. Aliansi Masyarakat Adat Nusantara (AMAN), HuMA dan Epistema Institute, dan United Nation Development Programme (UNDP) merupakan beberapa organisasi masyarakat sipil yang terlibat dalam diskursus penguatan kembali pengadilan adat.

Berbagai wacana yang berkembang mengenai penguatan pengadilan adat ini bermuara pada dua konsep besar mengenai bagaimana seharusnya kedudukan pengadilan adat dalam hubungannya dengan sistem peradilan nasional yang telah mapan. ${ }^{1}$ Pilihan pertama adalah mengintegrasikan pengadilan adat secara kelembagaan untuk masuk menjadi bagian dari sistem peradilan nasional. ${ }^{2}$ Usulanini dikemukakanuntukmemberikankekuatan mengikat yang lebih kokoh bagi putusan-putusan yang dibuat pengadilan adat. Pilihan yang kedua adalah penguatan substansial terhadap pengadilan adat tanpa diperlukan integrasi kelembagaan sebagaimana pilihan pertama. ${ }^{3}$ Sasaran yang ingin dicapai adalah dekonsentrasi beban perkara yang menumpuk di pengadilan negara, sehingga yang diperlukan adalah ketersediaan beragam pilihan bagi penyelesaian sengketa di masyarakat.

Berbagai aturan yang bersifat konstusional ${ }^{4}$ dan perundang-undangan menegaskan bahwa hukum adat sebagai hukum tidak tertulis yang tercermin dari nilai keadilan dan norma yang hidup dan tumbuh di masyarakat (the living law) adalah salah satu sumber hukum yang harus digali, diperhatikan dan dihormati terutama dalam praktik penegakan hukum. ${ }^{5}$ Dalam praktiknya pun hukum adat memang mendapat tempat dalam penyelenggaraan peradilan. ${ }^{6}$ Setidaknya hal ini tercermin dalam beberapa yurisprudensi yang dihasilkan oleh Mahkamah Agung dan lembaga peradilan di bawahnya. ${ }^{7}$ Oleh sebab itu, perlu dikaji berbagai perspektif dari sisi legal-normatif mengenai keberadaan pengadilan adat dan secara empiris dikaji implementasi aturan tersebut di dalam sistem peradilan perdata Indonesia.

Mendasarkan pada uraian permasalahan tersebut, penelitian ini berfokus pada dua hal, yaitu: Pertama, sejauh mana sistem peradilan perdata nasional memberi ruang bagi pengakuan dan kedudukan peradilan adat. Kedua, gambaran interkoneksi antara sistem peradilan perdata indonesia dengan peradilan adat.

\section{B. Metode Penelitian}

Penelitian ini menggunakan pendekatan normatif-empiris yang digunakan untuk melakukan analisis terhadap peraturan perundang-undangan maupun landasan normatif lainnya dalam kerangka hubungan pengadilan adat dengan sistem peradilan perdata. Data yang diperoleh melalui pendekatan normatif kemudian diuji kembali melalui pendapat dan hasil diskusi dari para narasumber.

1. Bahan Penelitian dan Cara Perolehan Bahan Penelitian

a. Penelitian Kepustakaan (Bahan Hukum Primer)

a) UU No. 1 Tahun 1951 tentang Undang-Undang Darurat tentang Tindakan-Tindakan Sementara untuk Menyelenggarakan Kesatuan Susunan,

Yance Arizona, "Kedudukan Peradilan Adat dalam Sistem Hukum Nasional", http://www.academia.edu/3723907/Kedudukan Peradilan Adat_dalam_Sistem_Hukum_Nasional, diakses 25 Februari 2014. Lihat juga Lilik Mulyadi, "Hukum dan Putusan Adat dalam Praktik Peradilan Negara", http://huma.orid/wp-content/uploads/2013/10/MAKALAH-1-.pdf, diakses 27 Februari 2014.

Ibid.

Ibid.

Lihat Pasal 18B ayat (1) dan (2) Undang-Undang Dasar Negara Repubik Indonesia Tahun 1945

Lihat Pasal 5 jo. Pasal 10 ayat (2) Undang-Undang Nomor 48 Tahun 2009 tentang Kekuasaan Kehakiman (Lembaran Negara Republik Indonesia Nomor 157 Tahun 2009, Tambahan Lembaran Negara Republik Indonesia Nomor 5076).

Sulastriyono dan Sandra Dini F. Aristya, 2011, Penerapan Norma dan Asas-Asas Hukum Adat dalam Praktik Peradilan Perdata, Hasil Penelitian, Unit Penelitian dan Pengabdian kepada Masyarakat, Fakultas Hukum Universitas Gadjah Mada, Yogyakarta.

Ibid. 
Kekuasaan dan Acara Pengadilan-Pengadilan Sipil;

b) UU No. 14 Tahun 1970 tentang Ketentuan-Ketentuan Pokok Kekuasaan Kehakiman;

c) UU No. 30 Tahun 1999 tentang Arbitrase dan Alternatif Penyelesaian Sengketa;

d) UU No. 4 Tahun 2004 tentang Kekuasaan Kehakiman;

e) UU No. 48 Tahun 2009 tentang kekuasaan Kehakiman;

f) Peraturan Presiden No. 6 Tahun 1966 tentang Penghapusan Pengadilan Adat/Swapraja dan Pembentukan Pengadilan Negeri di Irian Barat dihapus pula Pengadilan Adat/Swapraja di Irian Barat.

b. Penelitian Lapangan

Data yang diperoleh dari penelitian lapangan ini adalah data primer yang diperoleh langsung dari narasumber dengan metode wawancara jarak jauh melalui email. Narasumber terdiri atas 1 (satu) orang akademisi yang memiliki spesialisasi keilmuan di bidang hukum adat di Australia dan hukum Indonesia (aboriginal customary law, indigenous legal issues and Indonesian law) dan 1 (satu) orang hakim di Pengadilan Tinggi.

\section{Analisis Data}

Data primer dan data sekunder dianalisis dengan pendekatan kualitatif yang menghasilkan data yang deskriptif dan bersumber dari tulisan, ungkapan atau tingkah laku yang dapat diobservasi oleh manusia. ${ }^{8}$ Dari analisis kualitatif tersebut, diperoleh hasil penelitian yang bersifat deskriptif analitis. Bersifat deskriptif karena hasil penelitian ini memberikan gambaran yang utuh dan sistematis mengenai relevansi lembaga pengadilan adat terhadap sistem peradilan perdata di Indonesia. Bersifat analitis karena dilakukan suatu analisis terhadap berbagai aspek hukum tersebut untuk menjawab berbagai permasalahan yang telah diuraikan sebelumnya.

\section{Hasil Penelitian dan Pembahasan}

1. Pengakuan dan Kedudukan Peradilan Adat dalam Sistem Peradilan Perdata Nasional

Penelitian World Bank tentang keberadaan non-state justice (peradilan non-negara) menyimpulkan bahwa: Pertama, sistem peradilan informal adalah merupakan pengalaman keadilan satu-satunya bagi masyarakat; dan Kedua, berjalannya peradilan non negara sangat berdampak pada stabilitas sosial dan kesejahteraan masyarakat miskin. Penelitian ini juga memaparkan berbagai kekurangan dalam sistem peradilan adat atau nonnegara. meskipun begitu nampak optimisme untuk menggunakan mekanisme peradilan adat/non negara untuk menopang sistem pencapaian keadilan yang sudah dibangun oleh negara. ${ }^{9}$

UU Kekuasaan Kehakiman sejatinya masih memberi peluang bagi diselesaikannya suatu sengketa melalui mekanisme lain di luar peradilan negara. Pertanyaan selanjutnya adalah sejauh mana putusan-putusan peradilan adat dapat dipandang sebagai putusan perdamaian maupun arbitrase? Pertanyaan berikutnya sejauh mana Mahkamah Agung dan lembaga peradilan negara di bawahnya menghormati dan tunduk pada putusan perdamaian tersebut?

Selain pengakuan oleh peraturan perundangundangan, pengakuan terhadap peradilan adat perlu juga dikukuhkan oleh lembaga penegak hukum sebagai pihak yang secara langsung berurusan dengan sengketa-sengketa yang terjadi masyarakat. Selama ini sikap mengakui dan menghormatiputusan peradilan adat masih muncul secara parsial, terutama pada daerah-daerah yang memiliki basis hukum 
adat dan lembaga adat yang kuat. Penyelesaian sengketa berbasis komunitas salah satunya pernah dikuatkan oleh Pengadilan Tinggi Sumatera Barat melalui Surat Edaran Ketua Pengadilan Tinggi Sumatera Barat No. W3.DA.HT.04.02-3633 tanggal 27 Mei 1985 tentang Pemberlakuan Hukum Adat Minangkabau mengenai Sengketa Tanah Pusako Tinggi, dikuatkan dengan Surat Edaran Lembaga Kerapatan Adat Alam Minangkabau (LKAAM) No. 7/LKAAM-SB-VI-1985 tanggal 10 Juni 1985 perihal Penyelesaian Persengketaan Perdata Adat. ${ }^{10}$

Selain Pengadilan Tinggi Sumatera Barat, Pemerintah Daerah Sumbar melalui Perda No. 6 Tahun 2008 tentang Tanah Ulayat dan Pemanfaatannya, memberikan kewenangan kepada Kerapatan Adat Nagari (KAN) untuk menyelesaikan sengketa tanah ulayat di nagari. Pasal 12 Perda $a$ quo menyatakan bahwa sengketa tanah ulayat di nagari diselesaikan oleh KAN menurut ketentuan sepanjang adat yang berlaku, bajanjang naiak batanggo turun dan diusahakan dengan jalan perdamaian melalui musyawarah dan mufakat dalam bentuk keputusan perdamaian.

Lebih lanjut, dalam Pasal 13 Perda a quo diatur bahwa sengketa tanah ulayat yang melibatkan dua atau lebih nagari akan diselesaikan oleh KAN antar nagari. Kedua pasal di atas secara tegas menunjukkan bahwa Kerapatan Adat Nagari (KAN) diberikan kewenangan penuh untuk menyelesaikan sengketa perdata adat di tingkat komunitas atau nagari. Kewenangan tersebut tidak hanya diberikan oleh otoritas yudikatif (Pengadilan Tinggi) melainkan juga otoritas legislatif dan yudikatif (melalui Perda) di Sumatera Barat.

Besarnya kewenangan KAN dalam kehidupan adat istiadat di Sumatera Barat tidak hanya berada dalam wilayah penyelesaian sengketa. Keterlibatan pemuka adat dan lembaga-lembaga adat tidak hanya terbatas pada fungsi menengahi atau mengadili, yaitu sebagai reaksi terhadap sengketa-sengketa. Para pemuka adat di KAN juga memainkan peran penting di dalam mengurus kehidupan sosial lain di luar sengketa. Pada peristiwa-peristiwa sosial penting, terutama yang menyangkut status orang atau hubungan-hubungan terhadap properti (perkawinan, penguburan, peresmian pemangku adat, transaksi-transaksi properti) mereka bisa saja hadir atau mereka secara resmi diberitahukan dan harus memberikan persetujuan secara implisit atau eksplisit terhadap transaksi itu. ${ }^{11}$

Kewenangan KAN yang bercampur-baur tersebut, dalam perspektif pemisahan kekuasaan, tentu bukan suatu model yang ideal. Namun jika melihat efektifitas yang ditawarkan, kewenangan KAN dibidang eksekutif sekaligus yudikatif menawarkan solusi jika diterapkan di tataran komunitas yang jumlah anggotanya tidak terlalu besar.

Berkaitan dengan sifat dan kekuatan mengikat dari putusan KAN terhadap sengketasengketa yang terjadi di nagari, muncul pendapat yang menyatakan bahwa putusan KAN tersebut merupakan Keputusan Tata Usaha Negara (TUN). Pendapat ini didasarkan pada kedudukan KAN yang dibentuk dan disusun melalui Perda No. 13 Tahun 1983, tentang Nagari sebagai Kesatuan Masyarakat Hukum Adat jo. Perda No. 9 Tahun 2000 tentang Pemerintahan Nagari (dimana nagari diposisikan sebagai pengganti desa) jo. Perda No. 2 Tahun 2007 tentang Pemerintahan Nagari. Ketiga peraturan daerah tersebut memberikan kedudukan KAN sebagai badan atau pejabat yang melaksanakan urusan pemerintah berdasarkan peraturan perundang-undangan yang berlaku, oleh karena itu dianggap sebagai Pejabat Tata Usaha Negara sebagaimana diatur dalam ketentuan Pasal 1 angka 2 Undang-Undang No. 5 Tahun 1986 tentang Peradilan Tata Usaha Negara. Apabila

\footnotetext{
Kurnia Warman dan Albadri Arif, 2001, Laporan Hasil Observasi Community Justice di Sumatera Barat, Qbar dan Kemala, Padang. Keebet Von Benda Beckhman, 2000, Goyahnya Tangga Menuju Mufakat, Gramedia, Jakarta, hlm. 115.

Jomi Suhendri, "Penyelesaian Sengketa Tanah Pusako melalui Kerapatan Adat Nagari (KAN) di Nagari Situjuah Gadang (Studi Penerapan Peradilan Adat di Sumatera Barat)", Makalah, Konferensi dan Dialog Nasional "Negara Hukum Indonesia: Kemana Akan Melangkah?", Jakarta, 9 - 10 Oktober 2012, hlm. 8.
} 
KAN dianggap sebagai Pejabat Tata Usaha Negara, maka setiap keputusan yang dikeluarkan oleh KAN merupakan Keputusan Tata Usaha Negara yang dapat menjadi obyek sengketa di Peradilan Tata Usaha Negara. ${ }^{12}$

Pendapat di atas sejatinya mengandung beberapa kelemahan konseptual. Pertama, kedudukan KAN yang dipersamakan dengan badan atau Pejabat Tata Usaha Negara agaknya terlalu terburu-buru disimpulkan. Meskipun KAN diberikan kewenangan dalam menyelenggarakan pemerintahan adat, KAN tidak masuk dalam hierarki birokrasi pemerintahan negara atau yang kerap disebut dengan pemerintahan dinas. Kedua, kalaupun KAN dapat dianggap sebagai unit terkecil dari pemerintahan daerah, pendapat di atas mempersamakan konsep keputusan Pejabat Tata Usaha Negara (beschikking) dengan putusan KAN dalam penyelesaian sengketa. Meskipun KAN menjalanan dua fungsi sekaligus (sebagai penyelenggara pemerintahan sekaligus lembaga penyelesaian sengketa), kedua produk yang dihasilkannya sepantasnya tidak dianggap sebagai satu bangunan konsep. Meskipun obyek yang ditujunya sama-sama individual dan sempit, namun putusan tidak dapat diangap sebagai keputusan, terutama karena ada unsur sengketa yang melekat pada setiap putusan yang dihasilkan, sedangkan keputusan sendiri membawa sifat mengatur sebagai penyelenggara pemerintahan.

Pengaruh hukum adat terhadap penyelenggaraan sistem peradilan perdata nasional salah satunya dapat dilihat dari konteks sanksi yang diberikan. Konsep sanksi dalam pengadilan adat seharusnya dapat diadopsi oleh sistem peradilan perdata nasional. Fokus utama pada pemulihan keseimbangan, dalam konteks rasa keadilan masyarakat cenderung dapat diterima, dibandingkan dengan keputusan menang dan kalah yang selama ini mendominasi. Hal ini pula yang ditekankan dalam penelitian World Bank:
The imposition of sanctions through informal justice, however, does not tend to distinguish between criminal (public interest) and civil (private interest) infractions. This distinction is rarely made, particularly in tribal or clanbased societies, where private interests are often perceived through clan or familial lens. Restoration of harmony between clans and families is the resolution imperative. This likewise drives the nature of sanctions imposed..$^{13}$

Secara umum, berkaitan dengan kedudukan peradilan adat dalam sistem peradilan nasional, dapat ditarik beberapa catatan, antara lain:

1) Dominasi hukum negara menyebabkan putusan pengadilan adat menjadi tidak bertaji. Hukum adat seolaholah menjadi hukum pelengkap yang baru dapat diberlakukan apabila suatu kondisi belum diatur oleh hukum negara.

2) Pihak-pihak yang tidak puas dengan keputusan pengadilan adat dapat dengan mudah mengajukan pemeriksaan kembali kepada pengadilan negeri. Dalam konsep ini, pengadilan adat hanya akan menjadi sub-sistem dari peradilan negara, yang justru akan memperpanjang proses penyelesaian perkara karena harus melewati banyak tahapan pemeriksaan untuk sampai pada putusan yang final dan mengikat.

3) Intervensi negara yang terlalu besar terhadap lembaga peradilan adat. Intervensi ini dapat ditemukan dalam berbagai legislasi nasional dan daerah yang, meskipun di satu sisi memberikan penguatan kelembagaan, di sisi lain justru mengulangi kesalahan pemerintah kolonial dalam memperlakukan peradilan adat. Intervensi yang terlalu besar justru akan menghilangkan kemandirian komunitas dalam menyelesaikan sengketa-sengketa domestik mereka. Basis partisipasi masyarakat akan semakin lemah dan peradilan adat hanya akan menjadi perpanjangan

13 World Bank, Op.cit., hlm. 28. 
tangan dari kekuasaan negara. Akibat terburuknya, putusan yang dihasilkan tidak lagi mencerminkan jati diri dan rasa keadilan masyarakat melainkan melainkan menunjuk jalan yang disepakati oleh alat kekuasaan negara. Dampak dari kondisi ini akan sangat terasa apabila peradilan adat harus memutus sengketa yang melibatkan pihak luar (biasanya korporasi) sebagai salah satu pihak dalam perkara. Apabila keterikatan peradilan adat lebih kuat pada negara dibandingkan masyarakat adatnya, maka putusan akan cenderung berpihak pula sesuai arahan negara.

4) Integritas dan kapasitas hakim peradilan adat. Hingga saat ini belum ditemukan skema kaderisasi dan regenerasi hakim pengadilan adat yang ideal. Beban moral dan tanggung jawab hakim pengadilan adat tentu tidak lebih ringan dibandingkan hakim pengadilan negeri. Bahkan dalam beberapa hal, beban tersebut menjadi lebih berat karena hakim adat hidup bersama masyarakat sebagai anggota komunitas. Sehingga konflik kepentingan dan ancaman langsung dari komunitasnya sendiri apabila terjadi kesalahan dalam memutus perkara menjadi beban yang tidak ditemui pada hakim pengadilan negara.

5) Potensi penghakiman oleh mayoritas. Tidak dapat dipungkiri bahwa salah satu perbedaan peradilan adat dan peradilan negara terletak pada peran masyarakat dalam proses pemeriksaan dan pengambilan keputusan. Jika pengadilan negara cenderung dapat steril dari pengaruh langsung masyarakat di yurisdiksinya, tidak demikian halnya dengan pengadilan adat. Sebagai contoh, di Bali telah sejak lama dikenal istilah suryak siu untuk menggambarkan ketika putusan bersalah terhadap seseorang lebih ditentukan oleh teriakan bersamasama dari masyarakat yang hadir.
Biasanya suryak siu muncul dalam hal pelaku pelanggaran atau salah satu pihak yang bersengketa adalah orang yang memang sejak awal tidak disukai atau diterima di lingkungannya karena berbagai macam sebab. Kondisi trial by majority ini tentu bukan kondisi yang ideal dalam menemukan kebenaran dan mengembalikan keseimbangan di masyarakat yang terganggu karena adanya pelanggaran atau sengketa, tetapi justru mempertajam konflik dan ketimpangan relasi kuasa yang ditimbulkan dari hubungan mayoritas dan minoritas.

6) Sulitnya pembuktian formal dalam proses pemeriksaan di peradilan adat.

7) Kekuatan mengikat dan eksekutorial dari putusan pengadilan adat.

2. Interkoneksi antara Sistem Peradilan Perdata Nasional dengan Peradilan Adat

Paper yang dipublikasikan melalui UNDP menyebutkan bahwa dari 78 sistem hukum dari berbagai negara yang dikaji, banyak yang menyatakan bahwa informal justice systems hidup di negara yang bersangkutan namun tidak ada penjelasan yang rinci mengenai bagaimana hubungan antara sistem hukum lokal (local level system) dengan sistem negara (state regimes) terkait implementasi informal justice system tersebut. ${ }^{14}$

Peradilan adat merupakan terminologi normatif yang disebutkan dalam berbagai peraturan perundang-undangan. Namun terminologi legal formal tersebut dikenal dengan istilah yang berbeda oleh masyarakat. Beberapa masyarakat kesatuan hukum adat menyebut lembaga pengadilan adat dengan istilah yang beragam, misalnya "sidang adat", "para-para adat", "pokara adat", atau "rapat adat", serta berbagai istilah menurut kekhasan bahasa lokal setempat. ${ }^{15}$

Model penyelesaian sengketa berbasis komunitas di dunia internasional dikenal pula dengan banyak istilah. Munculnya berbagai istilah tersebut disebabkan karena beragamnya karakter dari

\footnotetext{
14 Ewa Wojkoswka, "How Informal Justice System Can Contribute", Paper, United Nations Development Program Oslo Governance Centre, Oslo, Desember 2006, hlm. 11.

15 Ibid.
} 
penyelesaian sengketa berbasis komunitas tersebut. Informal justice atau non state administered formal justice merupakan sebuah bentuk penyelesaian sengketa yang dibedakan dari state administered formal justice system. ${ }^{16}$ Hubungan antara informal justice dengan formal justice di berbagai negara tidak sama. Ada negara yang mengakui informal justice system secara legal-formal dan melembagakannya menurut hukum positif, namun ada juga yang tidak tegas mengaturnya dalam hukum negara (state law) namun tetap terdapat kolaborasi yang tidak resmi antara kedua sistem tersebut. ${ }^{17}$ Sebagai contoh negara yang mengakui informal justice secara legal formal adalah Cina. Informal justice system terwujud dalam People's Mediation Court (PMCs) yang dibentuk berdasarkan Constitution 1982. Lembaga ini berkembang dari sebuah lembaga tradisional yang lama berfungsi sebagai alternatif penyelesaian sengketa perdata di Cina.

Selain informal justice, istilah juga berkembang untuk menyebut penyelesaian sengketa alternatif sebagaimana peradilan adat di Indonesia. Beberapa tahun terakhir ini konsep community justice semakin berkembang khususnya di beberapa negara common law seperti Kanada dan Amerika Serikat. Pada hakikatnya community justice memiliki kesamaan dengan informal justice yaitu sama-sama penyelesaian konflik di luar peradilan negara. Namun jika dikaji lebih lanjut, community justice merupakan mekanisme penyelesaian konflik yang berhubungan dengan criminal justice atau pidana/kejahatan. Community justice merupakan sebuah sistem yang diciptakan untuk mencegah kejahatan dan melakukan penegakan keadilan yang melibatkan masyarakat (community) dengan tujuan untuk meningkatkan kualitas hidup masyarakat. ${ }^{18}$

Simplified court adalah model lain yang juga berkembang. Setidaknya ada dua bentuk peradilan yang dapat dikategorikan sebagai simplified court, yaitu peradilan desa (dorpjustitie) dan small claim court (SCC). Peradilan desa dan SCC sama-sama merupakan peradilan yang diakui oleh negara secara legal formal dalam artian terdapat peraturan perundang-undangan yang mengakui kedudukan kedua lembaga tersebut. Perbedaannya adalah peradilan desa diakui dan pernah berlaku di beberapa wilayah di Indonesia sedangkan SCC belum diakui dan belum berlaku di Indonesia.

Secara historis, peradilan desa dianggap mulai melemah eksistensinya sejak diberlakukannya Undang-Undang Kekuasaan Kehakiman pada masa lalu. Namun Lilik Mulyadi tidak sependapat jika dikatakan bahwa pengadilan desa dihapus berdasarkan undang-undang tersebut karena bertitik tolak dari ketentuan Pasal 1 ayat (3) Undang-Undang Darurat Nomor 1 Tahun 1951 yang menegaskan bahwa, "Ketentuan yang tersebut dalam ayat (1) tidak sedikitpun juga mengurangi hak kekuasaan yang sampai selama ini telah diberikan kepada hakim-hakim perdamaian di desa-desa sebagaimana dimaksud dalam Pasal 3a Rechterlijke Organisatie" dapat disimpulkan bahwa peradilan adat yang dihapuskan berdasarkan undang-undang darurat adalah peradilan adat dalam arti inheemsche rechtspraak, sedangkan kewenangan peradilan adat yang dilakukan oleh kepala-kepala kesatuan masyarakat hukum adat yaitu Peradilan Desa (dorpjustitie) tetap dilanjutkan. ${ }^{19}$

Alasan yang melandasi pendapat bahwa sesungguhnya sistem peradilan perdata memberikan pengakuan yang tegas terhadap eksistensi peradilan adat dan memberikan ruang yang luas bagi implementasi pengakuan tersebut yang meliputi:

a. Berlakunya ketentuan Pasal 130 HIR, 154 RBg yang mengatur kewajiban hakim untuk mendamaikan para pihak sebelum perkara diperiksa di persidangan. Betapa pentingnya upaya perdamaian hingga dibentuk Perma

Ibid., hlm. 9

UNICEF, "Informal Justice System (Charting a Course for Human Rights-Based Engagement): A Summary", http://www.unicef.org/ protection/files/INFORMAL JUSTICE SYSTEMS_SUMMARY.pdf, diakses 25 Juni 2014.

18 David R. Karp dan Todd R Clear, "Community Justice: A Conceptual Framework", https://www.skidmore.edu/campuslife/karp/book-chapters/ Community-Justice-A-Conceptual-Framework.pdf, diakses 20 Juni 2014.

19 Lilik Mulyadi, Op.cit., hlm. 6. 
Nomor 1 Tahun 2008 yang mewajibkan hakim untuk melaksanakan mediasi di pengadilan pada sidang pertama sebelum perkara diperiksa.

b. Berlakunya asas hakim aktif. Di dalam HIR sesungguhnya dianut asas hakim aktif yakni hakim selaku pimpinan sidang harus aktif memimpin pemeriksaan perkara dan tidak merupakan pegawai atau sekadar alat dari para pihak..$^{20}$ Asas ini juga sesuai dengan ketentuan dalam UndangUndang Kekuasaan Kehakiman yang menyatakan bahwa "Hakim membantu pencari keadilan dan berusaha mengatasi segala hambatan dan rintangan untuk dapat tercapainya peradilan yang sederhana, cepat, dan biaya ringan". ${ }^{21}$

c. Berlakunya asas sederhana, cepat dan biaya ringan. Meskipun asas ini ditujukan bagi penyelesaian perkara dan prosedur perdata di pengadilan, namun esensi dari asas ini sesungguhnya menunjukkan keberpihakan hukum acara perdata terhadap segala proses penyelesaian sengketa yang lebih efektif dan efisien bagi para pihak pencari keadilan.

d. Berlakunya asas judicare secundum allegata et probata atau dikenal sebagai asas hakim pasif. Sudikno Mertokusumo menyatakan bahwa berdasarkan asas ini, hakim terikat pada pokok perkara yang diajukan para pihak. ${ }^{22}$ Keterikatan itu sematamata menunjukkan bahwa hakim harus menghormati batasan dan luas ruang lingkup perkara yang ditetapkan para pihak. Hakim terikat pada peristiwa yang diajukan dan dibuktikan oleh para pihak di persidangan. ${ }^{23}$ Asas ini juga sesuai dengan asas yang disebut nemo judex sine actor (tidak ada perkara, tidak ada pengadilan). Oleh sebab itu, adalah hak para pihak yang bersengketa jika ingin menyelesaikan perkaranya secara damai di luar pengadilan meskipun mungkin perkara sudah sempat berjalan di persidangan. Perkara perdata adalah kepentingan perorangan. Para pihak masih memiliki hak untuk menarik diri dari pengadilan kapan saja selama disepakati.

e. Berlakunya asas ius curia novit (hakim dianggap tahu hukumnya). Asas ini menekankan agar hakim tidak sekadar menjadi corong atau mesin pembuat undang-undang, tapi hakim harus memiliki kemandirian dan kemampuan untuk menyelesaikan setiap persoalan yang diajukan kepadanya. Asas ini sesuai dengan ketentuan dalam Undang-Undang Kekuasaan Kehakiman yang mengatur bahwa "Hakim dan hakim konstitusi wajib menggali, mengikuti dan memahami nilai-nilai hukum dan rasa keadilan yang hidup dalam masyarakat". ${ }^{24}$

Lima asas tersebut mencerminkan landasan normatif yang seharusnya mendorong hakim sebagai pejabat yudisial negara untuk menghormati putusan-putusan peradilan adat di Indonesia. Dengan merujuk pada karakteristik peradilan adat sebagai informal justice, maka hubungan formal dan fungsional antara peradilan adat dan sistem peradilan perdata dapat dikaji salah satunya dengan mengidentifikasi praktik peradilan dalam mengakui dan mengormati keputusan-keputusan peradilan adat di Indonesia.

Untuk menggambarkan hubungan antara putusan pengadilan (yurisprudensi) dengan keputusan peradilan adat, peneliti mengidentifikasi beberapa putusan pengadilan (yurisprudensi) sebagai berikut:

a. Putusan Mahkamah Agung RI Nomor 436/K/Sip/1970 tanggal 16 Juni 1971. Kaidah hukum yang lahir dari

Sudikno Mertokusumo, Op.cit., hlm.13.

Pasal 4 ayat (2) Undang-Undang No. 48 Tahun 2009 tentang Kekuasaan Kehakiman (Lembaran Negara Republik Indonesia Nomor 157 Tahun 2009, Tambahan Lembaran Negara Republik Indonesia Nomor 5076).

Sudikno Mertokusumo, Op.cit., hlm. 12.

Ibid

Pasal 5 ayat (1) Undang-Undang No. 48 Tahun 2009 tentang Kekuasaan Kehakiman (Lembaran Negara Republik Indonesia Nomor 157 Tahun 2009, Tambahan Lembaran Negara Republik Indonesia Nomor 5076). 
putusan ini adalah bahwa Keputusan Adat Perdamaian Desa tidak mengikat Hakim Pengadilan Negeri dan hanya merupakan suatu pedoman sehingga kalau ada alasan hukum yang kuat Hakim Pengadilan Negeri dapat menyimpang dari keputusan tersebut.

b. Putusan Pengadilan Tinggi Bandung Nomor 137/1969/Perd/PTB tanggal 13 November 1969. Kaidah hukum yang lahir dari putusan ini adalah bahwa bukti surat perdamaian mengenai pembagian waris yang tidak dihadiri dan ditandatangani/ disetujui oleh pihak lainnya yang turut berkepentingan belum merupakan suatu ikrar (persetujuan dalam hukum adat), karenanya tidak mengikat pihakpihak dan tidak berkekuatan hukum.

c. Putusan Mahkamah Agung RI Nomor 361/K/Sip/1958 tanggal 29 November 1958. Kaidah hukum yang lahir dari putusan ini adalah bahwa pengadilan tidak berwenang untuk meninjau kembali suatu Putusan Desa mengenai sawah sanggan.

d. Putusan Mahkamah Agung RI Nomor 340/K/Sip/1958 tanggal 19 Desember 1958. Kaidah hukum yang lahir dari putusan ini adalah bahwa telah menjadi yurisprudensi tetap dari Mahkamah Agung bahwa tidak termasuk atribusi Hakim Negeri untuk meninjau benar/ tidaknya suatu Putusan Desa.

Dalam putusan-putusan tersebut nampak adanya hubungan yang fungsional antara pengadilan negara dengan keputusan peradilan adat, yang mana dalam hal ini pengadilan negara mengakui kewenangan yang dimiliki peradilan adat/ desa dalam menjatuhkan keputusan perdamaian meskipun keputusan itu tidak memiliki sifat yang mengikat bagi hakim.

Di dalam praktiknya, pengakuan hakim terhadap keputusan peradilan adat ini tercermin pada tahap mediasi di pengadilan sebelum sidang dilanjutkan oleh hakim. Hal ini dijelaskan oleh Elfi
Marzuni lebih lanjut sebagai berikut:

Peradilan adat tidak termasuk dalam sistem peradilan Negara, akan tetapi dalam praktik persidangan perkara perdata sekarang, penyelesaian peradilan adat itu terakomodir dan tercermin dalam ADR atau mediasi yang wajib dilaksanakan sebelum sidang dilanjutkan oleh Hakim. Hakim sering menemukan bahwa perkara tersebut sudah ada penyelesaiannya oleh Hakim Adat. Maka dalam hal ini penyelesaian melalui peradilan desa/adat yang sudah ada tersebut akan ditindak lanjuti dalam proses mediasi di Pengadilan dengan memotivasi supaya bisa dilaksanakan tanpa melanjutkan proses perkara. Akhirnya keputusan pengadilan adat tersebut dituangkan dalam Akta Perdamaian dengan suatu putusan Pengadilan dan putusan tersebut langsung berkekuatan hukum tetap. ${ }^{25}$

Selama ini praktik peradilan perdata sebenarnya telah mengakomodir asas dan norma hukum adat dalam penyelesaian suatu perkara di pengadilan. Sebagai contoh, Penetapan Pengadilan Negeri Bantul Nomor 22/PDT.P/2003/ PN.BTL tentang pergantian jenis kelamin dari wanita menjadi laki-laki dengan menerapkan asas "terang" yang merupakan asas dalam hukum adat. ${ }^{26}$ Selain itu terdapat Putusan Mahkamah Agung No. $3191 \mathrm{~K} / \mathrm{Pdt} / 1984$ tanggal 8 Februari $1989^{27}$ yang menyatakan bahwa dengan tidak dipenuhinya janji untuk mengawini tersebut, tergugat asal telah melanggar norma kesusilaan dan kepatutan dalam masyarakat dan perbuatan tergugat asal tersebut adalah suatu perbuatan melawan hukum, sehingga menimbulkan kerugian terhadap diri penggugat asal, maka tergugat asal wajib memberi ganti kerugian seperti apa yang tertera dalam amar putusan.

Berdasarkan uraian tersebut, dapat disimpulkan bahwa sistem peradilan perdata telah memberikan pengakuan baik secara normatif maupun secara praktis di dalam peradilan. Adapun implementasi dari pengakuan terhadap produk atau keputusan peradilan adat dapat diwujudkan dalam

\footnotetext{
Berdasarkan hasil wawancara dengan Elfi Marzuni (Hakim Pengadilan Tinggi DIY) pada 25 Juni 2014.

Sulastriyono dan Sandra Dini F. Aristya, Op.cit., hlm. 28.

Lilik Mulyadi, Op.cit., hlm. 18.
} 
tiga mekanisme, yaitu:

a. Menyepakati kembali keputusan peradilan adat dalam mediasi di pengadilan yang wajib dilakukan oleh hakim terhadap para pihak sebelum memeriksa perkara dan menuangkannya dalam putusan perdamaian (acte van vergelijk) yang isinya menghukum kedua belah pihak untuk memenuhi isi perdamaiannya yang telah dibuat melalui peradilan adat.

b. Menerima dan menilai keputusan peradilan adat tersebut sebagai bukti tertulis yang bisa disetarakan kekuatan pembuktiannya dengan akta di bawah tangan. ${ }^{28}$

c. Menerima dan menilai keputusan peradilan adat tersebut untuk ditarik menjadi persangkaan berdasarkan fakta atau kenyataan sebagai alat bukti. ${ }^{29}$

\section{Kesimpulan}

Berdasarkan hasil penelitian dan pembahasan yang telah disampaikan sebelumnya, maka diperoleh kesimpulan bahwa dalam sistem peradilan perdata, terdapat norma-norma dan asas-asas yang memberikan ruang teradap praktik peradilan adat yang memiliki perpaduan karakteristik sebagai informal justice, communal justice, APS, dan simplified court terlepas dari inkonsistensi dan ketidaktegasan peraturan perundang-undangan mengenai eksistensi peradilan adat di dalam sistem kekuasaan kehakiman Indonesia yang berlaku positif. Pengaruh kedudukan peradilan adat dalam sistem peradilan perdata terutama nampak dalam hubungannya yang fungsional antara keputusan peradilan adat dengan penyelesaian perkara perdata di pengadilan (yurisprudensi). Oleh sebab itu, untuk mengakomodir keberadaan keputusan peradilan adat, dalam praktiknya hakim akan mengoptimalkan mekanisme yang diatur di dalam sistem peradilan perdata seperti melalui mediasi di pengadilan.

Selain itu, kedudukan lembaga dan putusan pengadilan adat dalam sistem peradilan perdata nasional, meskipun secara parsial, masih diakui oleh peraturan perundang-undangan. Ironisnya, pengakuan lebih banyak muncul dalam peraturan perundang-undangan warisan kolonial seperti BW, HIR/Rbg. dan RO. Produk legislasi pasca kemerdekaan hingga reformasi justru banyak yang mencabut kedudukan dan kewenangan beberapa model pengadilan adat yang pernah hidup pada masa Hindia Belanda. Dalam ranah praktis saat ini, pengakuan tersebut semakin ambivalen. Pada satu sisi peradilan adat masih dihormati dan dirujuk dalam beberapa putusan hakim negara, namun di sisi yang lain kebijakan unifikasi badan peradilan mendorong terciptanya paradigma kekuasaan kehakiman yang hanya dimiliki Mahkamah Agung (berikut badan peradilan di bawah naungannya) dan Mahkamah Konstitusi. Akibatnya lembaga peradilan adat terposisikan hanya sebagai pelengkap manakala peradilan negara memerlukannya.

Adapun beberapa bahan rekomendasi dalam rangka menindaklanjuti kajian mengenai relevansi peradilan adat terhadap sistem peradilan perdata Indonesia ini, antara lain: Pertama, sistem peradilan perdata nasional saat ini adalah warisan pemerintahan kolonial yang dalam berbagai aspek sudah tertinggal dengan perkembangan hukum dan dinamika masyarakat. Oleh sebab itu, jika sistem peradilan adat akan berkembang ke suatu tahap tertentu, sistem hukum acara perdatanya harus pula disesuaikan. Kedua, perlu adanya pengaturan yang tegas mengenai keberadaan peradilan adat/desa dan hakim adat/desa serta pembagian kewenangan yang

\footnotetext{
28 Akta di bawah tangan ialah akta yang sengaja dibuat untuk pembuktian oleh para pihak tanpa bantuan dari seorang pejabat. Kekuatan pembuktian akta di bawah tangan sama seperti akta otentik yaitu sempurna, lengkap dan mengikat selama tandatangan dan isi dari akta tidak diingkari oleh salah satu pihak.

29 Penarikan persangkaan-persangkaan harus bersumber dari fakta-fakta yang telah terbukti dalam persidangan.
} 
jelas antara peradilan adat dengan peradilan negara terlalu berbeda di antara para hakim. sehingga tidak menimbulkan penafsiran yang

\section{DAFTAR PUSTAKA}

\section{A. Buku}

Beckhman, Keebet Von Benda, 2000, Goyahnya Tangga Menuju Mufakat, Gramedia, Jakarta.

Warman, Kurnia dan Albadri Arif, 2001, Laporan Hasil Observasi Community Justice di Sumatera Barat, Qbar dan Kemala, Padang.

World Bank, 2009, Forging The Middle Ground: Engaging Non-state Justice in Indonesia, World Bank, Jakarta.

\section{B. Hasil Penelitian}

Sulastriyono dan Sandra Dini F. Aristya, 2011, Penerapan Norma dan Asas-asas Hukum Adat dalam Praktik Peradilan Perdata, Hasil Penelitian, Unit Penelitian dan Pengabdian kepada Masyarakat, Fakultas Hukum Universitas Gadjah Mada, Yogyakarta.

\section{Makalah}

Suhendri, Jomi, "Penyelesaian Sengketa Tanah Pusako melalui Kerapatan Adat Nagari (KAN) di Nagari Situjuah Gadang (Studi Penerapan Peradilan Adat di Sumatera Barat)", Makalah, Konferensi dan Dialog Nasional "Negara Hukum Indonesia: Kemana Akan Melangkah?", Jakarta, 9-10 Oktober 2012.

Wojkoswka, Ewa, "How Informal Justice System Can Contribute", Paper, United Nations Development Program Oslo Governance Centre, Desember 2006.

\section{Artikel Internet}

Arizona, Yance, "Kedudukan Peradilan Adat Dalam Sistem Hukum Nasional", http:// www.academia.edu/3723907/Kedudukan Peradilan_Adat_dalam_Sistem_Hukum_ Nasional, diakses pada tanggal 25 Februari 2014. Lihat juga Lilik Mulyadi, "Hukum dan Putusan Adat dalam Praktik Peradilan Negara", http://huma.orid/wp-content/ uploads/2013/10/MAKALAH-1-.pdf, diakses 27 Februari 2014.

Karp, David R. dan Todd R Clear, "Community Justice: A Conceptual Framework", https:// www.skidmore.edu/campuslife/karp/bookchapters/Community-Justice-A-ConceptualFramework.pdf, diakses 20 Juni 2014.

UNICEF, "Informal Justice System (Charting a Course for Human Rights-Based Engagement): A Summary", http:// www.unicef.org/protection/files/ INFORMAL_JUSTICE_SYSTEMS_ SUMMARY.pdf, diakses 25 Juni 2014.

\section{E. Peraturan Perundang-Undangan}

Undang-Undang Dasar Negara Repubik Indonesia Tahun 1945.

Undang-Undang No. 48 Tahun 2009 tentang Kekuasaan Kehakiman (Lembaran Negara Republik Indonesia Nomor 157 Tahun 2009, Tambahan Lembaran Negara Republik Indonesia Nomor 5076). 